\title{
Орфографические ошибки, которые слышны в эфире
}

\author{
Михаил Штудинер
}

\begin{abstract}
Статья посвящена вопросам культуры русской речи в эфире. Цель публикации - обратить внимание радио- и тележурналистов на часто допускаемые ими у микрофона ошибки, специфика которых заключается в том, что эти же ошибки (можно предполагать с уверенностью) есть и в письменных текстах авторов передач. Такого же типа ошибки нередко можно услышать и в высказываниях представителей других речевых профессий.

Ключевые слова: культура речи в эфире, орфографическая ошибка, слабая фонетическая позиция, сильная фонетическая позиция, риторический вопрос.
\end{abstract}

DOI: 10.30547/mediaalmanah.5.2020.130133
() Штудинер Михаил Абрамович кандидат филологических наук, доцент кафедры стилистики русского языка факультета журналистики МГУ имени М.В. Ломоносова (Россия, г. Москва), studiner@mail.ru
В названии этой статьи нет кавычек, хотя на первый взгляд может показаться, что термин "орфографическая ошибка» употреблен здесь условно. Особенно если иметь в виду широко распространенное в учебно-методической литературе мнение о том, что орфографическая ошибка «может быть допущена только на письме и только в слабой фонетической позиции: для гласных - в безударном положении, для согласных - на конце слова или перед другим согласным» (Михайлова, 2019: 251). Авторы методических рекомендаций к ЕГЭ по русскому языку полагают, что «такую ошибку можно только увидеть, услышать ее нельзя» (Бисеров, 2013: 53-54). Профессор Алтайского государственного университета Л.Б. Парубченко еще в 2004 г. убедительно показала узость такого подхода и предложила классификацию орфографических ошибок.

Мы же в этой публикации ставим перед собой более скромную задачу: обратить внимание радио- и тележурналистов на часто допускаемые ими в эфире ошибки, специфика которых заключается в том, что эти же ошибки (можно предполагать с уверенностью) есть и в письменных текстах авторов передач. Такого же типа ошибки нередко можно услышать и в высказываниях представителей других речевых профессий. 
О высокой частотности рассматриваемых далее явлений свидетельствует также и то, что почти все примеры этого типа ошибок можно записать с эфира различных московских радио- и телеканалов в течение очень короткого периода - в течение двух-трех недель.

Речь идет об орфографических ошибках, которые обнаруживаются в устной речи в связи с действием фонетических закономерностей русского языка, причем обнаруживаются они именно в сильных фонетических позициях, то есть в позициях, благоприятных для тех или иных звуков, в позициях, в которых реализуется максимальный набор их качеств и в которых поэтому они лучше всего слышны: гласные под ударением, а согласные - перед гласными.

Рассмотрим некоторые из записанных нами с эфира примеров:

«Этот шаг принесет американским предпринимателям большие дивиденты (правильно: дивиденды)» (экономический обозреватель одной из московских радиостанций);

«Исследованиями реликвии занималась большая группа испанских ученых разных направлений - от физиков и историков до врачей-паталогоанатомов (правильно: патологоанатомов)» (радиокорреспондент) (к сожалению, в наше время бывают информационные поводы, заставляющие журналистов употреблять это слово, часто его произносят с ошибкой, не случайно после заголовка соответствующей статьи в «Википедии» дается запретительная помета: «не паталогоанатом»);

«...В бондарчуковском фильме с Аустерлицем, Бородиным (правильно: Бородином)» (из радиопередачи).

В сообщениях о праздновании различных юбилеев в сложных именах существительных и именах прилагательных с первой частью «сто-» ошибочно вместо «о» произносят «а»:

К стапятидесятилетию (правильно: к стопятидесятилетию) Банка России была вы- пущена монета из золота...» (из радиовыпуска новостей).

Это очень частотная ошибка. Приведем еще несколько примеров:

«Стадвадцатилетний (правильно: стодвадцатилетний) юбилей Михаила Исаковского, написавшего знаменитую «Катюшу» (из теленовостей).

«Стапятидесятилетие (правильно: стопятидесятилетие) со дня рождения Рахманинова будут отмечать в 2023 году» (из теленовостей).

Еще более частотными являются ошибки, связанные с выбором частиц не и ии.

В риторических вопросах часто вместо отрицательной частицы не в ударной позиции звучит усилительная частица ни:

«Кто только ни был (правильно: не был) членом этого английского клуба?» (из радиопередачи);

«Я служил и в городских храмах, и сельских, и в соборах. Где я только ни был (правильно: не был)! Где я только не служил!» (из выступления священника в радиоэфире). В последнем предложении в безударном положении не слышно, какая именно частица была произнесена: не или ни. Можно предположить, что была предпочтена частица иㅡ, как в предыдущем риторическом восклицании.

Еще один пример этой стилистической фигуры с ошибочным употреблением частицы:

«Кого там только ни было (правильно: не было)! Конечно, самые многочисленные и мощные - это ролевики, просто их вообще много. Были остатки хиппи, были панки, различные рокеры» (из телепередачи).

Необходимость употребления в русском риторическом вопросе отрицательной частицы обусловлена особенностями его устройства: для выражения утверждения риторический вопрос должен содержать средства отрицания - 르 или $\underline{\text { нет }}$, без них эта стилистическая фигура выражает отрицательный смысл (Иванова, 1982: 74-103). Сравните: 
За свою долгую жизнь с кем он только не встречался!

Каких книг здесь только нет! и

Разве это жизнь?

Первые две фразы означают «За свою долгую жизнь он встречался с самыми разными людьми» и «Здесь есть самые разные книги», а третья - «Это не жизнь».

Яркой иллюстрацией этой действующей в русском языке закономерности может служить стихотворение А.С. Пушкина 1831 г. «Клеветникам России»1, в котором есть много риторических вопросов:

Иль нам с Европой спорить ново?

Иль русский от побед отвык?

Иль мало нас? Или от Перми до Тавриды,

От финских хладных скал

до пламенной Колхиды,

От потрясенного Кремля

До стен недвижного Китая,

Стальной щетиною сверкая,

Не встанет русская земля?..

В приведенном фрагменте в каждом из первых трех риторических вопросов, в которых нет частицы еㅡ, выражается отрицание (не ново, не отвык, не мало), а в четвертом - с частицей не - утверждение.

Самая, пожалуй, частотная орфографическая ошибка, которую можно услышать в эфире, - это употребление частицы не вместо частицы ни в придаточных предложениях с усилительно-обобщенным значением - разновидности придаточных уступительных. Можно привести многочисленные примеры:

«Как бы не был (правильно: ни был) хорошо организован театр... но главного режиссера касается все» (главный режиссер одного из московских театров);

«Сейчас нужно отдохнуть после матча и сфокусироваться на следующем соперни-

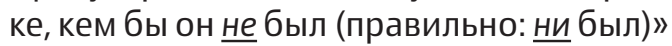
(телеведущая);

«Англичане никогда не пользуются своими банками, как бы не были (правильно: ни были) те популярны, надежны» (ведущий автомобильной программы одной из московских радиостанций);
«И в этом смысле, какой бы гость не был

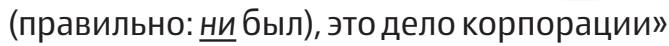
(главный редактор одной из московских радиостанций);

«Где бы мы не были (правильно: нет снега» (выдающаяся русская балерина);

«Неужели на предложение о помощи, каким бы оно не было (правильно: ни было), нужно отвечать таким образом?» (очень уважаемый политобозреватель);

«Надо писать правду о России, какая бы она не была (правильно: ни была» (выдающийся русский писатель в программе «Линия жизни»).

Во всех приведенных примерах орфографическая ошибка слышна, потому что частица под ударением. Но эта ошибка может быть слышна и в безударной позиции в очень старательной, четкой речи:

«И по стандарту, какие бы количества в продукте не присутствовали (правильно: $\underline{\text { ни }}$ присутствовали), указание на наличие сои или возможное наличие следов сои обязательно» (из выступления должностного лица в программе «Естественный отбор»).

В некоторых телевизионных передачах ключевые высказывания, звучащие в ходе эфира, воспроизводятся в субтитрах. В них иногда вместо частицы ни в придаточных уступительных предложениях ошибочно пишется частица не.

Распространенности орфографических ошибок, которые слышны в эфире, способствует тот факт, что они не очень сильно компрометируют говорящего, так как обычно не замечаются аудиторией. Эти ошибки не являются особенностью нашего времени. Их можно было услышать в эфире и раньше. Например, в фильме 1979 г. по пьесе Эжена Скриба «Стакан воды» один из персонажей произносит фразу: «Что бы там не было, мы должны доказать, что это была обычная дуэль» (правильно: «Что бы там ни было, мы должны доказать, что это была обычная дуэль».

Сейчас более высока степень частотности подобных ошибок. Это может объясняться, 
с одной стороны, тем, что многие передачи идут в прямом эфире, а с другой - все же недостаточным уровнем квалификации журналистов. Хотя эти ошибки есть не только в медиатекстах: они могут встречаться в звучащих текстах разных типов, в разных сферах общения.

На один курьезный случай, связанный с этим орфографическо-грамматическим явлением, обратила внимание И.Б. Левонтина в книге «Русский со словарем» (2010: 217-218).

В фильме 2003 г. режиссера Леонида Марягина «Здравствуй, столица» звучит песня композитора Сигизмунда Каца на стихи поэта Анатолия Софронова, которая была написана еще в 1947 г. Причем в фильме Леонида Марягина эта песня была исполнена в ретростилистике, так как режиссер стремился во всех деталях воспроизвести дух послевоенной эпохи. Но припев песни звучал так:

\footnotetext{
Здравствуй, столица,

Здравствуй, Москва,

Здравствуй, московское небо!

Каждому дороги эти слова,

Как далеко он бы ни был!
}

Произошел странный и неестественный для стиля песни сбой рифмы: небо - ни был. Поэт Анатолий Софронов, конечно, имел в виду более точную рифму: небо - не был. Так обычно и исполнялась эта песня: после всех трех куплетов в припеве звучало отчетливое не был.

Интересно, что в песенниках писали без орфографической ошибки, но исполняли всегда в рифму - не был.

«И вот как быть человеку, который столкнулся с дилеммой»: петь не в рифму или петь с ошибкой? И.Б. Левонтина (2010: 218) пишет: «Выбор непростой. Наверно, в душе режиссера Марягина эстет долго боролся с пуристом, прежде чем он принял решение в пользу лингвистической корректности и против благозвучия. Причем эта ошибка не был вместо ни был сейчас настолько типична, что громогласное ни не в рифму звучит почти как вопль отчаяния.

Пожалуй, тут дело не только в личных вкусах режиссера, но и в веяниях времени. Сейчас художник чувствует себя в своем праве, коль скоро дело касается рифм и прочих средств художественной выразительности. А вот погрешить против грамматики для интеллигентного человека пока еще невыносимо».

С радостью согласимся с этим оптимистичным выводом И.Б. Левонтиной.

\section{Примечания}

1 Пушкин А.С. Сочинения: в 3 т. М.: Худ. лит., 1985. Т. 1. С. 500.

\section{Библиография}

Бисеров А.Ю. ЕГЭ 2014. Русский язык. ГИА. ЕГЭ: нормы оценки знаний. М.: Яузапресс, 2013.

Иванова В.Ф. Трудные вопросы орфографии: пособие для учителей. М.: Просвещение, 1982.

Левонтина И.Б. Русский со словарем. М.: ИЦ «Азбуковник», 2010.

Михайлова Е.В. ЕГЭ 2020. Литература: алгоритм написания сочинения. М.: Эксмо, 2019.

Парубченко Л.Б. О классификации орфографических ошибок и о методических рекомендациях к ЕГЭ по русскому языку // Русский язык. Еженедельная газета объединения педагогических изданий «Первое сентября». 2004. № 16 (424). Режим доступа: https://rus.1sept.ru/article.php?ID=200401601 